\title{
Progression of radiological changes in rheumatoid arthritis
}

\author{
D. L. SCOTT,$^{1}$ K. A. GRINDULIS,${ }^{2}$ G. R. STRUTHERS, ${ }^{2} B \cdot{ }^{\prime}$. COULTON,${ }^{3}$ \\ A. J. POPERT, ${ }^{3}$ AND P.A. BACON ${ }^{1}$
}

From the ${ }^{1}$ Rheumatism Research Wing, the Medical School, University of Birmingham, Birmingham B15 2TJ; the ${ }^{2}$ Department of Rheumatology, Dudley Road Hospital, Birmingham B18; and ${ }^{3}$ Highfield Hospital, Droitwich Centre for Rheumatic Diseases, Droitwich, Worcestershire

SUMMARY A prospective study over one year of patients who had active rheumatoid arthritis discovered 64 who had received treatment for an adequate time with second-line drugs. In these patients there was evidence of continuing joint destruction as shown by radiological progression. During the year there were highly significant correlations between improvements in clinical and laboratory measurements, but neither group of tests was related to the degree of radiological change. However, in the second 6 months of treatment there was evidence that radiological progression was reduced. In a second prospective study of 88 patients with rheumatoid arthritis given prolonged, intensive therapy with second-line drugs and followed up for 10 years two-thirds showed radiological progression. However, the number of joints damaged per year fell significantly during the study period. There was a divergence between deterioration in radiological features and improvements in the ESR and functional capacity, though patients with a persistently low ESR had less radiological progression. These studies provide evidence that treatment may be associated with a reduced rate of radiological progression but suggest that changes in radiological progression and clinical and laboratory measurements may result from different mechanisms.

A variety of radiological changes occur in rheumatoid arthritis (RA). They include osteoporosis, bone erosions, loss of cartilage, subluxation, and secondary osteoarthritis. ${ }^{1}$ Active RA is characterised by radiological evidence of progressive joint damage, and if this radiological progression is reduced or prevented it may indicate control of the disease process. ${ }^{2-4} \mathrm{~A}$ variety of methods have been devised to assess radiological changes in RA which can be used to study their progression..$^{5-8}$

Drugs such as gold and penicillamine form an identifiable group of agents in RA, often termed 'secondline' or 'disease-modifying' drugs. They reduce not only the inflammatory synovitis but also the erythrocyte sedimentation rate (ESR) and the levels of acute-phase proteins such as C-reactive protein. ${ }^{9-14}$ These effects are not immediate but occur after a delay of weeks or months. Corticosteroids may also influence the acute-phase response, though their effects occur more rapidly. ${ }^{15}$

Accepted for publication 14 January 1983.

Correspondence to Dr D. L. Scott, Rheumatism Research Wing, The Medical School, University of Birmingham, Birmingham B15 2TJ.
Controlled studies of second-line drugs in RA have clearly shown that they decrease joint inflammation and the acute-phase response in comparison with placebos. ${ }^{16-21}$ Moreover, Amos et al. ${ }^{22}$ showed that patients in a steady state with persistently low ESRs and C-reactive protein levels had only minimal evidence of radiological progression compared with those patients in whom these indicators of the acutephase response stayed high. But many of the major placebo-controlled trials of drugs such as gold and penicillamine have failed to show any effect on radiological progression, despite significant reductions in the acute synovitis and acute-phase response. Thus, despite advances in understanding RA, the relationship of radiological changes to both clinical and laboratory features of the disease has not been completely elucidated.

Our objective was to refine the current concepts on the interrelationships between radiological changes and clinical and laboratory variables in RA, especially with respect to treatment with second-line drugs. We have done this in 2 complementary studies; one short-term (over one year) and one long-term (over 10 years). 


\section{Patients and methods}

1. SHORT - TERM ST UDY

Sixty-four patients with definite or classical RA (American Rheumatism Association criteria) were studied. They were selected from those entered into 2 prospective studies of second-line drugs in active RA. There were originally 102 patients in the studies; all had active disease with more than 1 hour of morning stiffness, 3 or more swollen tender joints, and a raised ESR ( $>30 \mathrm{~mm} / \mathrm{h})$. Only those followed prospectively for one year who had an adequate and continuous course of second-line drugs for at least 8 months were included in this study; of the 64 patients 44 were female and 20 male; their mean age was 47 years (range 19-76). They had had RA for a mean of 6 years (SD 6); 14 were in the first year of their disease and 18 had a history of RA for 10 or more years. The severity of their pretreatment RA is shown by a mean initial ESR of $51 \mathrm{~mm} / \mathrm{h}$ (SD 23) and mean Ritchie articular index ${ }^{27}$ of 21 (SD 15). They received penicillamine (16 patients), intramuscular sodium aurothiomalate (15 patients), Clozic (clobuzarit) (23 patients), and auranofin (10 patients). All 4 drugs have been investigated previously and have been shown to have second lineeffects. ${ }^{16-212425}$ The drugs were given for 8 months to 10 patients, 9 months to 2,10 months to 4 , and 12 months to 48 . All the patients had concomitant nonsteroidal anti-inflammatory drugs (such as aspirin and indomethacin); a wide variety of these agents was used. None of the patients had steroids.

Plain anteroposterior radiographs of both hands and wrists were taken before drug therapy and after 12 months. In 22 patients films were also taken after 6 months.

The films were read by 2 observers using the standard radiographs of Larsen et al., ${ }^{26}$ and the Larsen score was calculated as described. We have assessed the reproducibility of this in detailed technique and recorded our results elsewhere. ${ }^{27}$ In summary the 2 observers in this study gave the following results using this scoring system: single films: interobserver correlation $r=0.95(n=96)$, intraobserver correlations $r=0.97$ and $0.95(n=34)$; change in Larsen index using paired films: interobserver correlation $r=0.67$ $(n=48)$, intraobserver correlations $r=0.82$, and 0.69 $(n=34)$. This reproducibility was considered to be satisfactory. The Larsen index is on a scale of $0-150$. Each proximal interphalangeal, metacarpophalangeal, and wrist joint is graded on a $0-5$ scale from standard films. The score for the wrist joints is multiplied by 5 , and all the totals are then added to give an overall figure. Radiographs were read by the observers unaware of the date order or the response of the patients assessed clinically or by laboratory tests. A Larsen score was calculated for each film from a mean of the score given by each observer. From this the change in Larsen score could be derived for each patient between 0 and 12 months of the study; in 22 patients the changes at $0-6$ and $6-12$ months were also derived.

Three different clinical assessments were made in each patient at 0,6 , and 12 months: (a) grip strength measured with a standard sphygmonometer cuff inflated to $30 \mathrm{mmHg}$ (grip strength was measured 3 times in each hand and the mean value determined); (b) the Ritchie articular index ${ }^{23}$; (c) self assessment of pain by a visual analogue pain score, measured on a $10 \mathrm{~cm}$ scale.

Six laboratory assessments were also evaluated in each patient at 0,6 , and 12 months; the ESR (Westergren), haemoglobin concentration, Rose-Waaler titre, and measurements of immunoglobulins G, A, and $\mathrm{M}$. In 42 patients serum $\mathrm{C}$-reactive protein concentrations were also measured. These laboratory tests were performed by previously described standard laboratory techniques. ${ }^{10} 12$

Radiological, clinical, and laboratory changes were all ranked separately to indicate improvement during therapy. There were thus 3 rankings for each patient, which could vary from 1-64. The patient(s) showing the best response (by the degree of change) in each of these 3 sets of measurements was ranked 1 and the worst responder(s) 64 . The rankings referred only to the change during treatment, not to absolute initial or final values.

Radiological ranking was done on changes in the mean Larsen score. Those patients with the least deterioration received the best (i.e., lowest) rankings, while those with the greatest deterioration had the worst (i.e., highest) rankings.

Clinical rankings were based on the changes in all 3 clinical assessments at 0,6 , and 12 months. They were considered independently of either laboratory or radiological changes. Patients were arbitrarily ranked by their clinical response to treatment from best to worst by means of combined data from all 3 tests. This was done separately by 2 observers and the final ranking obtained from a mean of the 2 results. A similar procedure was used for laboratory assessments; once again changes in all the laboratory measurements were considered together for the laboratory rankings.

Rank correlations were performed by the method of Kendall ${ }^{28}$ with the appropriate procedure for tied ranks when these occurred. In addition rankings were grouped (into 4 groups of rankings) and compared by means of chi-square tests. Other data were expressed as means and standard errors where appropriate.

2. LONG-TERM STUDY

During $1964-76$ a prospective study was carried out 
at the Droitwich Centre for Rheumatic Diseases, a specialised rheumatology unit which acts as a referral centre for the West Midlands. In this study 112 patients were followed up for 10 years. All the patients had definite or classical RA. Consecutive patients with severe disease seen by one physician (A.J.P.) during 1964-8 and admitted to hospital at Droitwich for the treatment of their RA were included. The patients were assessed when first seen, at 5 years, and at 10 years. There were 80 females and 30 males. Their mean age was $45 \cdot 2$ years (range 21-72) and their mean disease duration $5 \cdot 2$ years (range 0.5-15).

All patients had similar intensive therapy. This included bed rest in the early stages and physiotherapy. They all received second-line drugs and/or steroids (only 5 patients received steroids alone). These were given over prolonged periods with the aim of suppressing disease activity as completely as possible. They were withdrawn only because of serious adverse reactions, lack of effect, or if a patient entered a prolonged remission. If one second-line drug was withdrawn and the patient was not in remission, another was started. In cases failing to respond these drugs were used in combination. Patients were seen regularly (in general at least every 6 months); if there was any indication of marked activity they were readmitted to hospital. They received the following second-line drugs for 3 months or longer: chloroquine in $72 \%$ of cases, gold in $79 \%$, penicillamine in $18 \%$, immunosuppressive drugs (azathioprine, chlorambucil, and cyclophosphamide) in $16 \%$, and corticosteroids in $91 \%$.

The initial, 5- and 10-year assessments included ESR, a modified Steinbroker functional capacity in 5 grades, ${ }^{29}$ Rose-Waaler titre, and plain anteroposterior radiographs of both hands and wrists. Radiographs were scored blindly by 2 independent observers and a reconciled grading was recorded. A modified Steinbroker grading was used.$^{29}$ One point could be scored for changes in the following joints: each proximal interphalangeal joint (except the thumb); each metacarpophalangeal joint; the intercarpal joints; and the radiocarpal joints. This gives a total of 0-22 possible points for each pair of hands. If one or more of the following changes were present in a joint one point was scored: cartilage loss, loss of alignment, secondary osteoarthritis, joint destruction. If the changes were questionable or if the joint was normal, no point was scored. Each joint was considered separately, and then the total score for the radiograph (varying from $0-22$ ) was made by addition of the points scored. Erosions alone did not score a point. The $x$-rays were read independently by 2 observers after preliminary studies had allowed definitions of significant changes to be agreed. If the observers scored the radiographs differently, they were reviewed again and a reconciled grading was reached. For this reason no formal assessment of reproducibility was made, although in practice disagreements were extremely uncommon.

Change in the various parameters was assessed by grading into 3-6 groups as follows. The ESR was classified into 3 groups - low $(20 \mathrm{~mm} / \mathrm{h}$ or less), medium $21-49 \mathrm{~mm} / \mathrm{h})$, or high $(50 \mathrm{~mm} / \mathrm{h}$ or none); the functional capacity was graded into 5 modified Steinbroker grades $^{29}$; the Rose-Waaler titre was classified into 3 groups as negative, weakly positive (1:32 or less), or strongly positive (1:64 or none); the number of damaged joints (scored as above) were grouped into 6 categories - no damaged joints, 1-5, 6-10,11-15, 16-20, and 21-22. For each parameter a change in category was analysed at 5 and 10 years by comparison with the initial category.

The relative rate of radiological progression was also assessed. The number of joints damaged at the start of the study was related to the duration of RA (in years) to give an 'initial' (prestudy) rate of radiological progression expressed as joints damaged per year. The number of joints damaged during the 10-year period of study was then related to the exact follow-up period (in years) to give the rate of radiological progression during the study expressed as joints damaged per year. In both instances the 0-22 point grading system described above was used to determine the number of damaged joints.

Of the 112 patients entering the study 1 died before 5 years. By 10 years a further 16 patients had died, 5 had moved away from Droitwich and for 2 the $x$-rays were not available; 88 patients were therefore available for follow-up at 10 years.

\section{Results}

\section{SHORT-TERM ST UDY}

Radiological changes during the 12 months of this study, assessed by the Larsen index, are shown in Fig. 1. Radiological progression occurred in 57 patients $(89 \%)$; at best patients showed no significant deterioration. The majority of patients did not initially have severe joint destruction; the mean Larsen score at the beginning of the study was $45 \cdot 4$. The mean change was an increase of $8.9(20 \%$ of initial value); the maximum was an increase of $34(380 \%$ of initial value) during the year. Progression was equally likely in those with minimal radiological evidence of joint damage at the beginning of treatment as in those whose initial joint damage was severe.

The $x$-ray changes can be contrasted with those seen in the ESR (Fig. 2); 47 patients (73\%) showed an improvement in their ESR during the year but for only 28 patients ( $43 \%$ ) was the final ESR $20 \mathrm{~mm} / \mathrm{h}$ or 


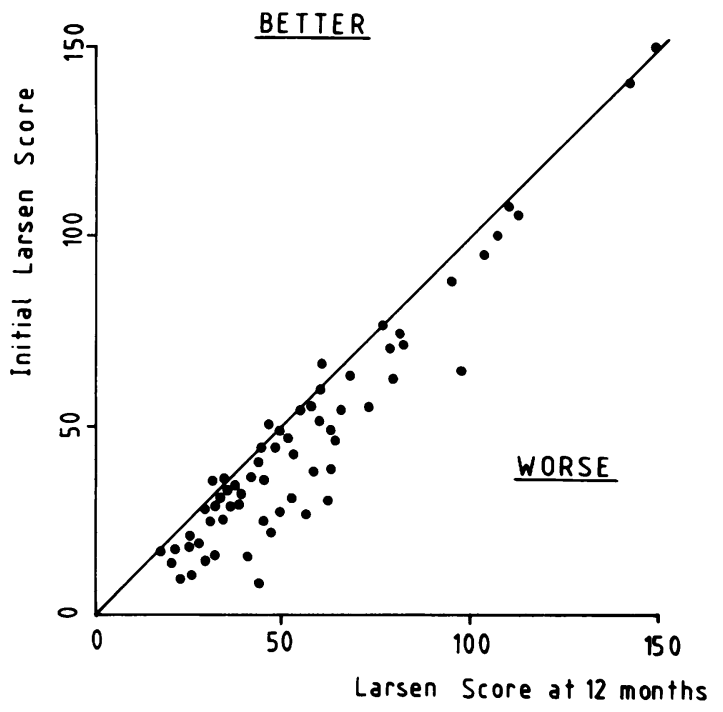

Fig. 1 Short-term study. Scatter diagram showing changes in Larsen score during one year of treatment with second line drugs. A $45^{\circ}$ no-change line is indicated.

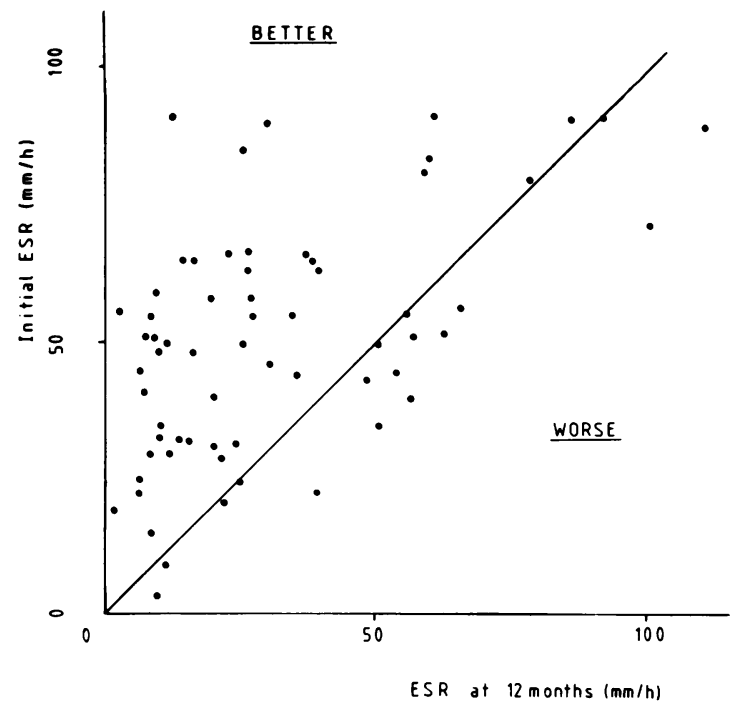

Fig. 2 Short-term study. Similar scatter diagram showing changes in ESR during one year of treatment with second-line drugs.

less. Changes in the ESR showed a wide scatter and the final ESR was relatively independent of the initial value. In comparison the $x$-rays not only showed deterioration but the final Larsen score (the absolute score as opposed to the rate of change) was dependent on the initial $x$-ray score.
When patients were ranked by the severity of their radiological progression (based on changes in the Larsen score), there was no significant correlation with ranking for either improvements in laboratory tests or clinical measurements (analysis by Kendall's rank correlation test). Similarly when these comparisons were made by grouped rankings, there was still no evidence of a significant relationship (Tables 1 and 2). On the other hand when the rankings for clinical and laboratory improvements were compared, these were significantly related $(p<0 \cdot 001$, Kendall's rank correlation test) and this was also shown by grouped rankings (Table 3 ).

It could be argued that the failure to demonstrate a relationship between radiological changes and both clinical and laboratory changes resulted from difficulties in satisfactory ranking of the radiological changes. For this reason we have further compared the clinical and laboratory changes in those patients

Table 1 Short-term study. Relationship of radiological change (assessed by change in Larsen index) to change in laboratory indices of disease activity. Patients have been ranked from 1-64 for both parameters; those with the lowest rankings had the best response (i.e., least radiological change or best overall improvement in laboratory tests); those with the lowest rankings did worst. Tied ranks occurred in some cases. The expected numbers in each group (if the null hypothesis were true) are shown in parentheses.

\begin{tabular}{llllll}
\hline $\begin{array}{l}\text { Ranking for } \\
\text { changes in } x \text {-rays }\end{array}$ & \multicolumn{4}{l}{ Ranking for changes in laboratory tests } \\
& & \multicolumn{2}{l}{ Best } & & Worst \\
\cline { 3 - 6 } & & $1-16$ & $17-32$ & $33-48$ & $49-64$ \\
\hline Best & $1-16$ & $6(4 \cdot 5)$ & $3(4 \cdot 5)$ & $4(4 \cdot 5)$ & $5(4 \cdot 5)$ \\
& $17-32$ & $4(3)$ & $3(3)$ & $3(3)$ & $2(3)$ \\
& $33-48$ & $4(4 \cdot 5)$ & $4(4 \cdot 5)$ & $4(4 \cdot 5)$ & $6(4 \cdot 5)$ \\
Worst & $49-64$ & $2(4)$ & $6(4)$ & $5(4)$ & $3(4)$ \\
\end{tabular}

$\chi^{2}=4 \cdot 9, \mathrm{DF}=9, \mathrm{p}>0 \cdot 05$.

Table 2 Short-term study. Relationship of radiological change (assessed by change in Larsen index) to change in clinical parameters of disease activity. This is arranged similarly to Table 1

\begin{tabular}{lrllll}
\hline $\begin{array}{l}\text { Ranking for } \\
\text { change in } x \text {-rays }\end{array}$ & \multicolumn{2}{l}{ Ranking for change in clinical assessments } \\
& & Best & & & Worst \\
\cline { 2 - 6 } & & $1-16$ & $17-32$ & $33-48$ & $49-64$ \\
\hline Best & $1-16$ & $5(4 \cdot 5)$ & $5(4 \cdot 5)$ & $7(4 \cdot 5)$ & $1(4 \cdot 5)$ \\
& $17-32$ & $5(3)$ & $2(3)$ & $2(3)$ & $3(3)$ \\
& $33-48$ & $3(4 \cdot 5)$ & $6(4 \cdot 5)$ & $3(4 \cdot 5)$ & $6(4 \cdot 5)$ \\
Worst & $49-64$ & $3(4)$ & $3(4)$ & $4(4)$ & $6(4)$ \\
\hline
\end{tabular}

$\chi^{2}=10 \cdot 9, \mathrm{DF}=9, \mathrm{p}>0 \cdot 10$. 
Table 3 Short-term study. Relationship of changes in clinical parameters to those in laboratory assessments of disease activity. This is arranged similarly to Table 1

\begin{tabular}{lrrrrl}
\hline $\begin{array}{l}\text { Ranking for } \\
\text { changes in } \\
\text { laboratory } \\
\text { assessments }\end{array}$ & \multicolumn{4}{l}{ Ranking for change in clinical assessments } \\
& \multicolumn{1}{l}{ Best } & & & Worst \\
\cline { 2 - 6 } & $1-16$ & $17-32$ & $33-48$ & $49-64$ \\
\hline Best & $1-16$ & $13(4)$ & $2(4)$ & $0(4)$ & $1(4)$ \\
& $17-32$ & $2(4)$ & $5(4)$ & $5(4)$ & $4(4)$ \\
& $33-48$ & $1(4)$ & $7(4)$ & $4(4)$ & $4(4)$ \\
Worst & $49-64$ & $0(4)$ & $2(4)$ & $7(4)$ & $7(4)$ \\
\hline
\end{tabular}

$\chi^{2}=43 \cdot 0, D F=9, p<0 \cdot 001$.

with the greatest radiological changes and those with the least change (Table 4). In these patients there can be no question of difficulties in determining their radiological grouping. However, the 2 groups showed similar changes in clinical and laboratory measurements, which is further evidence for the divergence of radiological changes in this short assessment over a period of rapid change.

It would be expected from previous studies and the preceding results that disease duration would be a major factor determining the extent of joint damage in patients with severe disease. Table 5 shows that there was a highly significant correlation between the initial Larsen score and disease duration. There was also some evidence, in our highly selected group of patients, that the initial Larsen score might be related to the initial disease activity; and this had a weak association with immunoglobulin levels and grip strength (Table 5), though the low values show that single measurements of these parameters have a low predictive value. The indices which can have large interpatient variations, such as the Ritchie index, were unrelated to radiological changes by this method of analysis.

An analysis of radiological changes in relation to the initial degree of joint damage is shown in Table 6. This indicates that a considerable proportion of change is due to radiological damage of joints which, at the beginning of the study, were normal or only slightly involved. It suggests that there is a general deterioration, involving all degrees of damage.

In 22 patients the $x$-rays at 6 months were evaluated in addition to those at 0 and 12 months. There was some evidence that the rate of progression had slowed during the 6-12 month period. In these $x$-rays the mean initial Larsen score was 33.9 (SEM 3.9); the 6-month value 39.1 (SEM 4.0), and the 12-month value $41 \cdot 4$ (SEM 3.6). Thus $69 \%$ of the total change occurred in the first 6 months and only $31 \%$ in the period $6-12$ months.

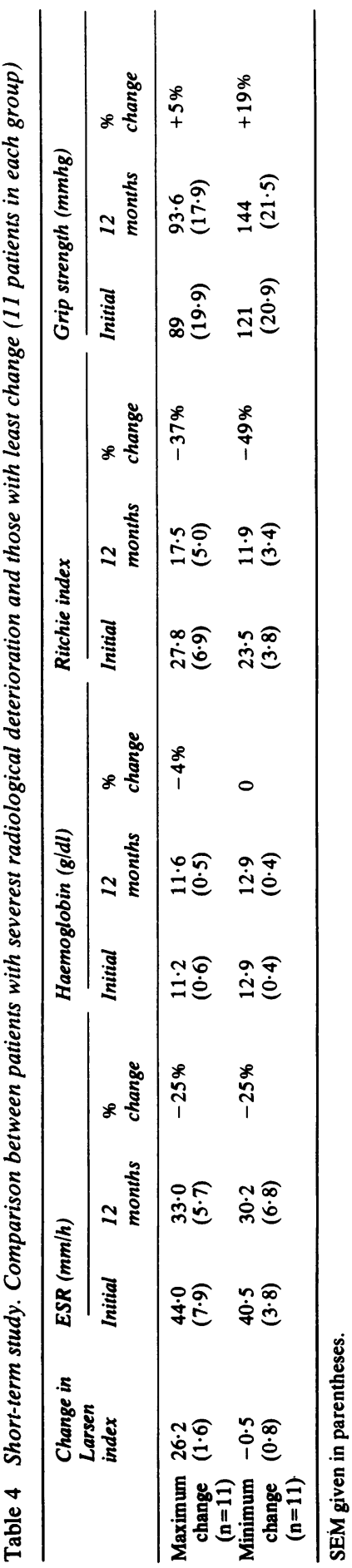


Table 5 Short-term study. Relationship of radiological assessment (initial Larsen index) to disease duration and the clinical and laboratory measurements in the patients with $R A(n=64)$

\begin{tabular}{lll}
\hline Parameter & $\begin{array}{l}\text { Correlation } \\
\text { coefficient }(r)\end{array}$ & Probability \\
\hline Disease duration (years) & +0.52 & $\mathrm{p}<0.001$ \\
ESR (mm/h) & +0.20 & $\mathrm{p}<0.10$ \\
Haemoglobin (g/d) & -0.09 & $\mathrm{p}>0.10$ \\
IgG (g/l) & +0.26 & $\mathrm{p}<0.05$ \\
IgA (g/l) & +0.21 & $\mathrm{p}<0.10$ \\
IgM (g/l) & +0.37 & $\mathrm{p}<0.01$ \\
Grip strength (mmHg) & -0.27 & $\mathrm{p}<0.05$ \\
Ritchie articular index & +0.09 & $\mathrm{p}>0.10$ \\
Visual analogue pain & & $\mathrm{p}>0.10$ \\
$\quad$ assessment & +0.02 & \\
\hline
\end{tabular}

Table 6 Short-term study. Relationship of changes in Larsen index to the initial degree of joint damage

\begin{tabular}{|c|c|c|c|}
\hline $\begin{array}{l}\text { Joints in each } \\
\text { category of }\end{array}$ & $\begin{array}{l}\text { Initial (\%) } \\
(n=1562)\end{array}$ & $\begin{array}{l}\text { Final (\%) } \\
(n=1562)\end{array}$ & $\begin{array}{l}\text { Change in } \\
\text { category (\%) }\end{array}$ \\
\hline 0 & $39.1 \%$ & $29.8 \%$ & $-9 \cdot 3 \%$ \\
\hline 1 & $33.0 \%$ & $32 \cdot 3 \%$ & $-0.7 \%$ \\
\hline 2 & $15 \cdot 5 \%$ & $20.9 \%$ & $+5.7 \%$ \\
\hline 3 & $4.6 \%$ & $6.9 \%$ & $+2 \cdot 3 \%$ \\
\hline 4 & $2.9 \%$ & $3.6 \%$ & $+0.7 \%$ \\
\hline 5 & $5 \cdot 2 \%$ & $6 \cdot 5 \%$ & $+1 \cdot 3 \%$ \\
\hline
\end{tabular}

We also analysed the effect of a low ESR in the second 6 months of the study. Patients with an ESR at both 6 and 12 months of $25 \mathrm{~mm} / \mathrm{h}$ or less were compared with other patients. They had less radiological progression. The patients with the low ESRs had, over the 12 months, a mean change in Larsen score of $7 \cdot 5($ SEM $1 \cdot 52, n=32)$; those with higher ESRs had a mean change in Larsen score of $10 \cdot 7(\mathrm{SEM} 1 \cdot 70, \mathrm{n}=32)$. These differences were not significant at the $5 \%$ level, but they were compatible with the view that a reduced ESR is associated with less radiological deterioration.

\section{LONG-TERM ST UDY}

The divergence between the laboratory and radiological changes seen in the short-term study was also seen in the long-term study by the somewhat different method of radiological assessment of a modified Steinbroker grading. Thus, while there were improvements in the ESR, functional capacity, and Rose-Waaler titre in many patients at 5 and 10 years, there was a considerable deterioration in the radiological changes. This is summarised for grouped results in Table 7.

There was some evidence that treatment was associated with a reduced rate of $x$-ray progression. The rate of loss of joints prior to treatment was significantly greater than that during the 10-year period of the study. The mean initial rate of loss was 1.37 joints damaged per year (SD 1.96); the rate of loss during the study was 0.53 joints damaged per year (SD 0.56), a highly significant reduction $(p<0.001)$. This is shown in Fig. 3 .

Patients who had a low ESR had considerably less radiological progression than those with a persistently high ESR (Table 8). though only a small number of patients fell into the latter group. Comparing the extent of radiological progression at 5 years in patients with a persistently low ESR (less than 20 $\mathrm{mm} / \mathrm{h}$ ) with that of all other patients showed that these had significantly less progression $(p<0.05)$, as shown in Table 9.

In the short-term study we showed that at a point in

Table 7 Long-term study. Changes in parameters measured

\begin{tabular}{|c|c|c|c|c|c|c|c|c|}
\hline & \multicolumn{4}{|c|}{5 years $(n=111)$} & \multicolumn{4}{|c|}{10 years $(n=111)$} \\
\hline & ESR & $\begin{array}{l}\text { Rose-Waaler } \\
\text { titre }\end{array}$ & $\begin{array}{l}\text { Functional } \\
\text { capacity }\end{array}$ & Radiographs & $E S R$ & $\begin{array}{l}\text { Rose-Waaler } \\
\text { titre }\end{array}$ & $\begin{array}{l}\text { Functional } \\
\text { capacity }\end{array}$ & Radiographs \\
\hline $\begin{array}{r}\text { Improved } 2 \text { or } \\
\text { more classes }\end{array}$ & $9 \%$ & $14 \%$ & $7 \%$ & 0 & $9 \%$ & $16 \%$ & $23 \%$ & 0 \\
\hline Improved 1 class & $35 \%$ & $17 \%$ & $41 \%$ & 0 & $31 \%$ & $15 \%$ & $42 \%$ & 0 \\
\hline $\begin{array}{l}\text { No change } \\
\text { Deteriorated }\end{array}$ & $45 \%$ & $50 \%$ & $44 \%$ & $47 \%$ & $47 \%$ & $46 \%$ & $23 \%$ & $33 \%$ \\
\hline 1 class & $10 \%$ & $15 \%$ & $8 \%$ & $34 \%$ & $11 \%$ & $19 \%$ & $10 \%$ & $31 \%$ \\
\hline $\begin{array}{c}\text { Deteriorated } 2 \text { or } \\
\text { more classes }\end{array}$ & $1 \%$ & $4 \%$ & 0 & $19 \%$ & $2 \%$ & $4 \%$ & $2 \%$ & $36 \%$ \\
\hline
\end{tabular}

Classes

ESR: $20 \mathrm{~mm} / \mathrm{h}$ or less; $21-49 \mathrm{~mm} / \mathrm{h} ; 50 \mathrm{~mm} / \mathrm{h}$ or more.

Rose-Waaler titre: negative; $1: 32$ or less; $1: 6$ or more.

Functional capacity: classes I-V of modified Steinbroker grading.

Radiographs: 0, 1-5, 11-15, 16-20, 20-22 joints damaged. 


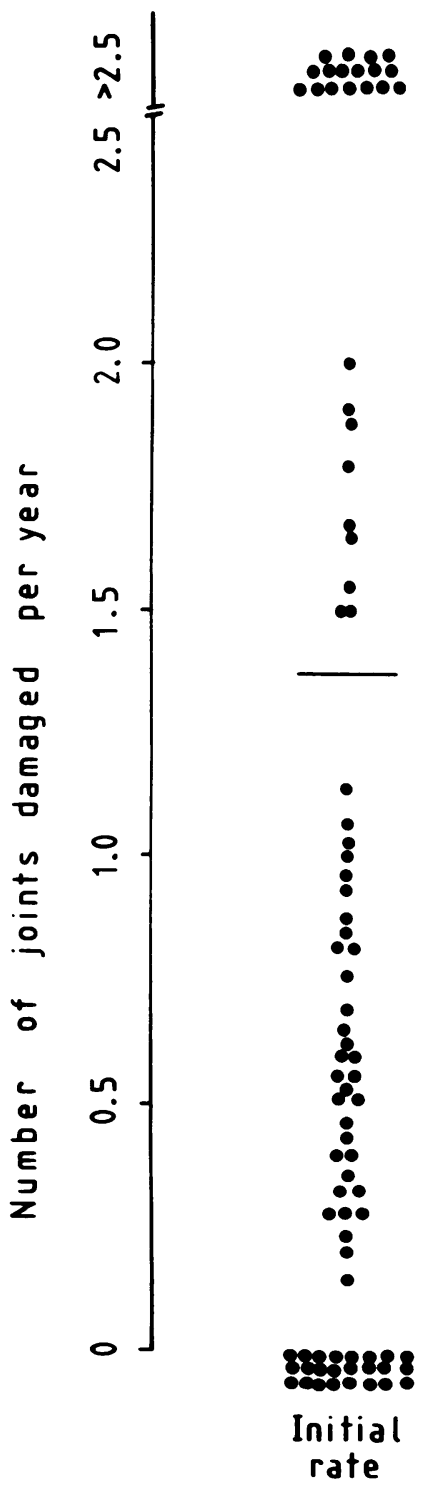

Fig. 3 Long-term study. Rate of radiological progression: initial (prestudy) rate and rate during study period shown. The means for each group are shown by horizontal bars. There was a significant reduction in the rate of joint damage $(p<0.001)$

time the extent of radiological damage was related to disease duration. We have therefore examined whether, in the long term, $x$-ray progression is also influenced by disease duration. But we found no evidence of this (Table 10).
Table 8 Long-term study. Relationship of ESR to radiological progression (selected patients with low and high ESR)

\begin{tabular}{|c|c|c|c|c|}
\hline \multirow{2}{*}{$\begin{array}{l}\text { Radiological } \\
\text { change }\end{array}$} & \multicolumn{2}{|l|}{5 years } & \multicolumn{2}{|l|}{10 years } \\
\hline & $\begin{array}{l}\text { Low ESR, } \\
1-20 \mathrm{~mm} / \mathrm{h} \\
(n=19)\end{array}$ & $\begin{array}{l}\text { High ESR, } \\
50 \mathrm{~mm} / \mathrm{h} \\
(\mathrm{n}=10)\end{array}$ & $\begin{array}{l}\text { Low ESR, } \\
1-20 \mathrm{~mm} / \mathrm{h} \\
(n=13)\end{array}$ & $\begin{array}{l}\text { High ESR, } \\
50 \mathrm{~mm} / \mathrm{h} \\
(\mathrm{n}=3)\end{array}$ \\
\hline $\begin{array}{l}\text { No change } \\
\text { Deteriorated }\end{array}$ & 13 & 4 & 6 & 0 \\
\hline $\begin{array}{l}1 \text { group } \\
\text { Deteriorated } \\
\text { by } 2 \text { or more } \\
\text { groups }\end{array}$ & 5 & 4 & 4 & 1 \\
\hline
\end{tabular}

Table 9 Long-term study. Relationship of ESR to radiological progression (comparing patients with low ESR to all other cases at 5 years)

\begin{tabular}{lll}
\hline $\begin{array}{l}\text { Radiological } \\
\text { change }\end{array}$ & $\begin{array}{l}\text { ESR always } \\
1-20 \mathrm{~mm} / \mathrm{h} \\
(n=19)\end{array}$ & $\begin{array}{l}\text { Other patients } \\
(\mathrm{n}=92)\end{array}$ \\
& &
\end{tabular}

\begin{tabular}{lcc}
\hline $\begin{array}{l}\text { No change } \\
x \text {-rays show } \\
\text { deterioration }\end{array}$ & 13 & 39 \\
\hline
\end{tabular}

$\chi^{2}=4 \cdot 28, \mathrm{DF}=1, \mathrm{p}>0.05$.

Table 10 Long-term study. Relationship of disease duration prior to treatment to subsequent radiological progression

\begin{tabular}{|c|c|c|c|}
\hline \multirow{2}{*}{$\begin{array}{l}X \text {-ray } \\
\text { progression }\end{array}$} & \multicolumn{3}{|c|}{ Disease duration when first seen } \\
\hline & $\begin{array}{l}\text { Less than } \\
18 \text { Months } \\
(n=27)\end{array}$ & $\begin{array}{l}18 \text { months } \\
\text { to } 5 \text { years } \\
(n=36)\end{array}$ & $\begin{array}{l}\text { More than } \\
5 \text { years } \\
(n=25)\end{array}$ \\
\hline $\begin{array}{l}\text { Improved } \\
\text { No change } \\
\text { Deteriorated }\end{array}$ & $\begin{array}{l}44 \% \\
30 \% \\
26 \%\end{array}$ & $\begin{array}{l}56 \% \\
14 \% \\
30 \%\end{array}$ & $\begin{array}{l}36 \% \\
44 \% \\
20 \%\end{array}$ \\
\hline
\end{tabular}

\section{Discussion}

Acute joint inflammation and the acute-phase response are readily controlled in patients with RA given second-line drugs. Radiological progression is less easily influenced; it may be reduced only when the acute-phase response and chronic joint inflammation are completely controlled. There thus appears to be a rather indirect relationship between the acute-phase response and radiological changes. Amos et al. ${ }^{22}$ have previously shown that in a steady state a low level of joint inflammation and of acutephase protein is associated with minimal radiological progression. It may be necessary to suppress joint 
inflammation and the acute-phase response for as long as one year before subsequent radiological progression is satisfactorily controlled. In the short term radiological progression may show a divergence from both the acute-phase response and joint inflammation, as was clearly shown in our first (one year) study, where there was no correlation between radiological progression and either laboratory changes (representing various components of the acute-phase response) and clinical changes (representing measurements of acute joint inflammation). However, there was an important and highly significant correlation in this short-term study between laboratory and clinical variables. The long-term study also showed a marked divergence between improvements seen in the ESR and continuing radiological progression.

The radiological assessments we have used in the 2 studies are somewhat different and are not directly comparable. The Larsen index is for erosions - the most specific, the earliest,$^{30}$ and probably the most sensitive index of radiological change in RA - and it is therefore suitable for a short-term assessment. On the other hand erosive changes are not necessarily a cause of poor function in a joint, unlike cartilage loss or loss of alignment, and in the long-term study we have chosen to measure these by using a modified Steinbroker index. However, despite the differences in assessments the conclusions from both studies are similar.

Why should this radiological deterioration occur if patients have apparently been adequately treated with second-line drugs? Disease duration is one factor. Our patients covered the whole range of time of presentation and were not confined to early or late disease. A recent report ${ }^{31}$ has shown that in patients with early disease radiological progression may be reduced by treatment with Clozic (clobuzarit). However, Bitter ${ }^{32}$ has suggested that many patients who meet the diagnostic criteria of the American Rheumatism Association for classical or definite RA in the early years of their disease have a mild selflimiting disorder unlike those with progressive RA.

The drop-out rate is another important factor. Although gold, penicillamine, and similar secondline drugs will lead to clinical improvements in most patients, in short-term studies approximately $30 \%$ of patients will withdraw due to lack of effect or unacceptable adverse reactions. ${ }^{33-35}$ Over a period of 2-5 years the majority of patients will discontinue therapy when a single drug is used ${ }^{36}{ }^{37}(\mathrm{~K}$. Grindulis and B. McConkey, in preparation). Even combination therapy with a variety of second-line drugs and steroids may still not control the disease adequately in all cases. Bearing in mind the delayed effect of treatment upon radiological changes, we found the reasons for continuing radiological deterioration became clearer. Nevertheless there was some evidence that treatment over all was associated with a reduced rate of radiological progression. The 22 patients whose radiographs were evaluated between both 0-6 and 6-12 months in the short-term study showed less progression in the latter period while receiving second-line drugs. The long-term study also showed a significant reduction in the rate of radiological progression during the period of the study. A retrospective survey by Luukkainen et al. ${ }^{3839}$ has shown a similar effect; patients receiving a full course of treatment with gold had less radiological progression than patients receiving an inadequate course. However, their selection of patients is open to criticism.

The concept that there is a division between acute inflammatory synovitis and acute-phase protein changes on the one hand and joint destruction on the other is supported by the pathological findings in RA. Histologically the inflamed synovium differs from the pannus - which is considered to lead to the tissue destruction and remodelling that underlies the radiological changes. ${ }^{4041}$ While an acute inflammatory synovitis is the earliest change in $\mathrm{RA}^{4},^{42}{ }^{43}$ the pannus is a later development. Collagenase and possibly other proteolytic enzymes located at the cartilagepannus junction are involved in cartilage destruction, ${ }^{44-46}$ and bone changes follow this. Inherent in this process are changes in connective tissue matrix involving collagen, fibronectin, and other connective tissue proteins. ${ }^{47}{ }^{48}$ These changes are controlled by variety of factors - most of which are small polypeptides. ${ }^{49-52}$ Some of these have been identified in rheumatoid synovial fluid. ${ }^{53}$ In these circumstances the remodelling of the connective tissue of bones and joints which underlies radiological changes is probably not directly influenced by the factors controlling acute inflammation and the acute-phase protein response - which explains the indirect relationship we have observed.

Three previous studies have shown a significant reduction in radiological progression during therapy with second-line drugs. Sigler et al. ${ }^{18}$ showed that gold given for 2 years reduced the rate of radiological progression in patients with RA, though it did not abolish it. The only other controlled studies to show a significant effect of therapy on radiological changes were when high doses of immunosuppressive drugs were given - high dose steroids in one case ${ }^{54}$ and cyclophosphamide in the other. ${ }^{55}$ This suggests that either prolonged control of the acute inflammatory response or therapy with drugs which can affect a wide variety of cells (such as cytotoxic drugs) is necessary to reduce radiological progression, and is in keeping with our conclusion that there is an indirect 
relationship between the acute-phase response and radiological changes.

We thank Drs B. McConkey, D. D. Felix-Davies, and J. P. Delamere for their help and advice.

D. L. Scott and P. A. Bacon are in receipt of grants from the Arthritis and Rheumatism Council.

\section{References}

1 Genant H K. Radiology of rheumatic diseases. In: McCarty D J, ed. Arthritis and allied conditions. Philadelphia: Lea and Febiger, 1979: 70-130.

2 Huskisson E C. Routine drug treatment of rheumatoid arthritis and other rheumatic conditions. Clin Rheum Dis 1979; 5: 697-706.

3 Wright V, Amos R. Do drugs change the course of rheumatoid arthritis? Br Med J 1980; 280: 964-6.

4 Anonymous. Inducing remission in rheumatoid arthritis (Editorial). Lancet 1981; i: 193-4.

5 Kellgren J H, Jeffrey M R, Ball J. Atlas of standard radiographs of arthritis. Oxford: Blackwell, 1963.

6 Sharp J T, Lidsky M D, Collins L C, Moreland J. Methods of scoring the progression of radiological changes in rheumatoid arthritis. Arthritis Rheum 1971; 14: 706-20.

7 Larsen A. Radiological grading of rheumatoid arthritis; an inter observer study. Scand J Rheumatol 1973; 2: 136-8.

8 Smith D W, Bluhm G B. Rater reliability in reading PA films of hands for bone and cartilage changes in rheumatoid arthritis. Eur J Rheumatol Inflamm 1982; 5: 198-255.

9 McConkey B, Crockson R A, Crockson A P. The assessment of rheumatoid arthritis. Q J Med 1972; 41: 115-25.

10 McConkey B. Crockson R A, Crockson A P, Williamson A R. The effects of some anti-inflammatory drugs on the acute-phase proteins in rheumatoid arthritis. $Q J$ Med 1973; 42: 785-91.

11 Constable T J, Crockson R A, Crockson A P, McConkey B Drug treatment of rheumatoid arthritis. Lancet 1975; i: 1176-9.

12 McConkey B, Davies P, Crockson R A, Crockson A P, Butler M. Constable T J. Dapsone in rheumatoid arthritis. Rheumatol Rehabil 1976; 15: 230-4.

13 McConkey B. New drugs for inflammation. Agents Actions 1976; 6: 593-5.

14 Amos R S, Crockson R A, Crockson A P, Walsh L, McConkey B. Rheumatoid arthritis: C-reactive protein and erythrocyte sedimentation rate during initial treatment. Br Med J 1978; i: 1396.

15 McConkey B, Davies P, Crockson R A, et al. Effects of gold, dapsone, and prednisolone on serum $C$-reactive protein and haptoglobin and the erythrocyte sedimentation rate in rheumatoid arthritis. Ann Rheum Dis 1979; 38: 141-4.

16 Research subcommittee of the Empire Rheumatism Council. Gold therapy in rheumatoid arthritis. Report of a multicentre controlled trial. Ann Rheum Dis 1960; 19: 95-117.

17 Co-operating clinics Committee of the American Rheumatism Association. A controlled trial of gold salt therapy in rheumatoid arthritis. Arthritis Rheum 1973; 16: 353-8.

18 Sigler J W, Bluhm G B, Duncan H, Sharp, J T, Ensign D C, McCrann W R. Gold salts in the treatment of rheumatoid arthritis. A double-blind study. Ann Intern Med 1974; 80: 21-6.

19 Multicentre Trial Group. Controlled trial of D-penicillamine in severe rheumatoid arthritis. Lancet 1973; i: 275-80.

20 Shiokawa Y, Horiuchi Y, Honma M, Kageyama T, Okada T, Azuma T. Clinical evaluation of D-penicillamine by multicentre double-blind comparative study in chronic rheumatoid arthritis. Arthritis Rheum 1977; 20: 1464-72.

21 Dixon A St J, Davis J, Dormandy T L, et al. Synthetic D-penicillamine in rheumatoid arthritis. Double blind controlled study of a high and low dose regimen. Ann Rheum Dis 1973; 34: 416-21.
22 Amos R S, Constable T J, Crockson R A, Crockson A P, McConkey B. Rheumatoid arthritis; relation of serum C-reactive protein and erythrocyte sedimentation rates to radiographic changes. $\mathrm{Br}$ Med J 1977; i: 195-7.

23 Ritchie D, Boyle J A, McInnes J M, et al. Clinical studies with an articular index for the assessment of joint tenderness in patients with rheumatoid arthritis. $Q J$ Med 1968; 37: 393-406.

24 McConkey B, Amos R S, Billingham M E J, et al. Rheumatoid arthritis; effects of a new agent (ICI 55897) on serum acutephase proteins and the erythrocyte sedimentation rate. Ann Rheum Dis 1980; 39: 18-21.

25 Weisman M H, Hannifin D M. Management of rheumatoid arthritis with oral gold. Arthritis Rheum 1979; 22: 922-5.

26 Larsen A, Dale K, Eck M. Radiographic evaluation of rheumatoid arthritis and released conditions by standard reference films. Acta Radiol (diagn) (Stockh) 1977; 18: 481-91.

27 Grindulis K A, Scott D L, Struthers G R. The assessment of radiological progression in the hands and wrists in rheumatoid arthritis. Rheumatol Int in press.

28 Kendall M G. Rank correlation methods . 4th ed. London: Griffin, 1970.

29 Steinbroker O, Traeger C H, Batterman R C. Therapeutic criteria in rheumatoid arthritis. JAMA 1949; 140: 659-62.

30 Brook A, Corbett M. Radiographic Changes in early rheumatoid disease. Ann Rheum Dis 1977; 36: 71-3.

31 Rushton A, Bird H A, Wright V. Assessment of $x$-ray progression in a controlled therapeutic study using a new visual analogue scoring system. Ann Rheum Dis in press.

32 Bitter T. A new look at rhe umatoid arthritis. In: Wright V, ed. Topical reviews in rheumatoid disorders. Bristol: Wright, 1982: 2.

33 Rothermich N O, Phillips V K, Bergen W, Thomas M H. Crysotherapy. A prospective study. Arthritis Rheum 1976; 19: 1321-7.

34 Kean W F, Anastassiades T P. Long term chrysotherapy. Arthritis Rheum 1979; 22: 495-507.

35 Hill H F H, Penicillamine in rheumatoid arthritis: adverse effects. Scand J Rheumatol 1979; 28 (suppl): 94-9.

36 Rothermich N O, Phillips V K, Bergen W, Thomas M H. Follow-up study of crysotherapy. Arthritis Rheum 1979; 22: 423.

37 Rothermich N O, Thomas M H, Phillips V K, Bergen W. Clinical trial of penicillamine in rheumatoid arthritis. Arthritis Rheum 1981; 24: 1473-8.

38 Luukkainen $\mathrm{R}$, Kajander A, Isomaki H. Effect of gold on progression of erosions in rheumatoid arthritis. Scand $J$ Rheum 1977; 6: 189-92.

39 Luukkainen R, Isomaki $\mathrm{H}$, Kajander A. Effect of gold treatment on the progression of erosions in RA patients. Scand. $J$ Rheumatol 1977; 6: 123-27.

40 Gardner D L. The pathology of rheumatoid arthritis. London: Amold, 1972.

41 Fassbender H G. The pathology of rheumatic diseases (trans. G. Loewi). Berlin: Springer, 1975.

42 Kulka J P, Bocking D, Ropes M W, Bauer W. Early joint lesions of rheumatoid arthritis; a report of eight cases, with knee joint biopsies in lesions of less than one year's duration. Arch Pathol 1955; 59: 129-50.

43 Moberg E, Wassen E, Kjellberg S R, Zettergren L, Scheller S, Aschan $W$. The early pathological changes in rheumatoid arthritis. Acta Chir Scand 1966; 357: 142-7.

44 Evanson J M, Jeffrey J J, Krane S M. Studies on collagenase from rheumatoid synovium in tissue culture. J Clin Invest 1968 ; 47: 2639-51.

45 Woolley D E, Crossley M J, Evanson J M. Collagenase at sites of cartilage erosion in the rheumatoid joint. Arthritis Rheum 1977; 20: 1231-9.

46 Dayer J M, Goldring S R, Robinson D R, Krane S M, Cell-cell interactions and collagenase production. In: Woolley $D E$, Evanson J M, eds. Collagenase in normal and pathological connective tissues. Chichester: Wiley, 1980: 83-104. 
47 Scott D L, Wainwright A C, Walton K W, Williamson N. Significance of fibronectin in rheumatoid arthritis and osteoarthritis. Ann Rheum Dis 1981; 40: 142-53.

48 Scott D L, Delamere J P, Walton K W. The distribution of fibronectin in the pannus in rheumatoid arthritis. $B r J$ Exp Pathol 1981; 62: 362-8.

49 Aalto $M$, Kulonen $\mathrm{E}$. Inhibition of protein synthesis in tendon cells by extracts from experimental granulation tissue. FEBS Lett 1974; 49: 70-2.

50 Castor C W, Lewis R B. Connective tissue activation X. Current Studies on the process and its mediators. Scand J Rheumatol 1976; 5 (suppl 12) 41-54.

51 Aalto $M$, Kulonen $E$. Fractionation of connective-tissueactivating factors from the culture medium of silica-treated macrophages. Acta Pathol Microbiol Scand 1979; 87C: 241-50.
52 Aalto $\mathrm{M}$, Turakainen $\mathrm{H}$, kulonen E. Effect of $\mathrm{SiO}_{2}$-liberated macrophage factor on protein synthesis in connective tissue in vitro. Scand J clin Lab Invest 1979; 39: 205-13.

53 Kulonen E, Potila M. Macrophages and the synthesis of connective tissue components. Acta Pathol Microbiol Scand 1980; 88C: 7-13.

54 Joint Committee of the Medical Research Council and the Nuffield Foundation. A comparison of prednisolone with aspirin or other analgesics in the treatment of rheumatoid arthritis. Ann Rheum Dis 1959; 18: 173-86.

55 Co-operating Clinics Committee of the American Rheumatism Association. A controlled trial of cyclophosphamide in theumatoid arthritis. $N$ Engl J Med 1970; 283: 883-9. 